\title{
Life Cycle Assessment (LCA) of an Integrated Biomass Gasification Combined Cycle (IBGCC) with $\mathrm{CO}_{2}$ removal
}

\author{
Matteo Carpentieri * Andrea Corti, Lidia Lombardi \\ Dipartimento di Energetica "Sergio Stecco", University of Florence \\ Via Santa Marta 3, 50139 Firenze - Italy \\ Tel +39055 4796349, Fax +39055 4796342 \\ E - mail: matteo.carpentieri@pin.unifi.it - corti@pin.unifi.it - lidia@pin.unifi.it \\ ${ }^{*}=$ corresponding author
}

\section{SUMMARY}

Basing on results of previous studies, the efficiency of a Brayton/Hirn combined cycle, fuelled with a clean syngas produced by means of biomass gasification and equipped with $\mathrm{CO}_{2}$ removal by chemical absorption, resulted $33.94 \%$, considering also the separated $\mathrm{CO}_{2}$ compression process. The specific $\mathrm{CO}_{2}$ emission of the power plant was $178 \mathrm{~kg} / \mathrm{MWh}$. In comparison with values previously found for an Integrated Coal Gasification Combined Cycle (ICGCC) with upstream $\mathrm{CO}_{2}$ chemical absorption (38-39\% efficiency, $130 \mathrm{~kg} / \mathrm{MWh}$ specific $\mathrm{CO}_{2}$ emissions), this configuration seems to be attractive because of the possibility of operating with a simplified scheme and for the possibility of using biomass in a more efficient way with respect to conventional systems.

In this paper a Life Cycle Assessment (LCA) was carried out presenting results on the basis of the Eco-Indicator'95 impact assessment methodology. Further, a comparison with the results previously obtained for the LCA of the ICGCC was performed, in order to highlight environmental impact of biomass production with fossil fuels utilisation.

The LCA shows the important environmental advantages of biomass utilisation in terms of reduction of both greenhouse gas emissions and natural resource depletion, although an improved impact assessment methodology may better highlight the advantages due to the biomass utilisation. 


\section{INTRODUCTION}

The study of a gasification process producing syngas for high performance thermodynamic cycle was carried out in two steps:

1. simulation of the gasification process, gas purification and its utilisation in the energy production cycle, performed in a previous study and reported for clarity in the present paper (Corti and Lombardi, 2002).

2. Life Cycle Assessment of the cycle, including biomass production (energy crops) and plant construction/dismantling, presented in this paper.

The schematic of the Integrated Biomass Gasification Combined Cycle (IBGCC) is shown in figure 1 and consists basically in biomass gasification and syngas cleaning before its utilisation in a conventional combined cycle (Brayton/Hirn).

The aim of the process is to obtain a gas with high hydrogen content and low carbon dioxide content, suitable for the utilisation in a gas turbine.

Biomass and air are fed to an atmospheric pressure gasifier. The obtained syngas is first driven to a cyclone, to remove solid particles, and thus supplied to a catalytic shift reactor to convert carbon monoxide into hydrogen and carbon dioxide, using steam. The goal of this process is to increase $\mathrm{H}_{2}$ and $\mathrm{CO}_{2}$ concentrations before $\mathrm{CO}_{2}$ removal.

Downstream the shift reaction process, a $\mathrm{CO}_{2}$ removal is performed in order to reduce greenhouse gas emissions and to produce a higher LHV fuel. This process consists in chemical absorption by means of an aqueous amine blended solution (diethanolamine, DEA, and methyldiethanolamine, MDEA). In this way, a syngas with high hydrogen content is obtained and then fed to the combustion chamber of the gas turbine.

The energy conversion is obtained by means of a conventional combined cycle, integrated with many energy recovers along the process. Steam from the steam turbine is extracted in order to supply the energy requirement for both amine regeneration and shift reaction process.

The simulation was performed by means of a model (Carpentieri 2001) developed with Aspen Plus 10.1-0 (AspenTech 2001). 


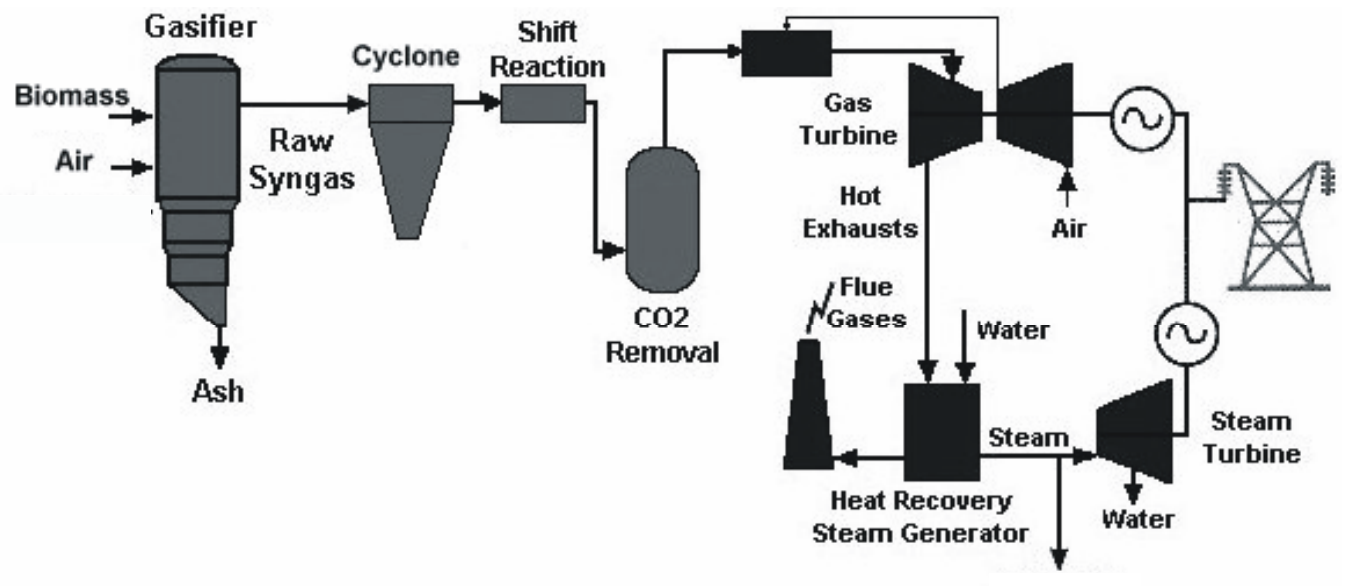

Figure 1 Schematic of the IBGCC $+\mathrm{DeCO}_{2}$

\section{GASIFICATION PROCESS AND SHIFT REACTION}

The gasification reactor, simulated as an equilibrium reactor, is fed with biomass (fixed flow rate 31 $\mathrm{kg} / \mathrm{s}$ ) and air, and produces raw syngas and sludge. The considered biomass (table 1) has a Low Heating Value (LHV) of about 18,000 kJ/kg (Domalski and Jobe 1987).

\begin{tabular}{|c|c|c|c|}
\hline \multicolumn{2}{|c|}{ Proximate analysis } & \multicolumn{2}{c|}{ Ultimate analysis } \\
\hline Moisture & $15 \%$ & Ash & $1.34 \%$ \\
\hline Fixed Carbon & $16.35 \%$ & Carbon & $48.45 \%$ \\
\hline Volatile Matter & $82.32 \%$ & Hydrogen & $5.85 \%$ \\
\hline Ash & $1.33 \%$ & Nitrogen & $0.47 \%$ \\
\hline \multirow{2}{*}{} & Chlorine & $0.1 \%$ \\
\cline { 2 - 3 } & Sulfur & $0.01 \%$ \\
\cline { 2 - 3 } & Oxygen & $43.78 \%$ \\
\hline
\end{tabular}

Table 1 Biomass composition (poplar). Mass fractions

Generally, a gasification process is fed with an oxidant medium (air or oxygen) and steam, this last to promote the shift reaction. In this study no steam is fed to the gasifier, since the presence of a devoted shift reaction section assures the $\mathrm{CO}$ conversion into $\mathrm{CO}_{2}$ to take place later, even with higher conversion rate.

The inlet air flow rate was adjusted to obtain the best result in term of LHV of the raw syngas. The result is a low value for the gasification air ratio $\left(e=\right.$ Air/Air $\left._{\text {stech }}=0.2\right)($ Carpentieri 2001). 
An atmospheric pressure gasifier was chosen (Carpentieri 2001) because of the higher development level of this technology (Williams and Larson 1996).

The composition of the produced syngas was calculated by means of the chemical processes simulator Aspen Plus (Carpentieri 2001); the gasifier was theoretically modelled as an equilibrium reactor.

According to figure 2, the raw syngas is first cooled (HE1), then is fed to the cyclone, where $95 \%$ of fly ashes and all the unconverted carbon are removed and recirculated back to the gasifier.

The shift section consists of a two stage process with a high temperature reactor $\left(450^{\circ} \mathrm{C}\right)$ and a low temperature reactor $\left(250^{\circ} \mathrm{C}\right)$. The whole amount of steam required for the two reactors (extracted form the steam turbine) is fed to the first reactor (Chiesa and Consonni 1998, Hendriks 1994).

The exothermic reaction, that consists in the conversion of carbon monoxide and steam into carbon dioxide and hydrogen, is the following:

$$
\mathrm{CO}+\mathrm{H}_{2} \mathrm{O} \rightarrow \mathrm{CO}_{2}+\mathrm{H}_{2}+44.477 \mathrm{MJ} / \mathrm{mol}_{\mathrm{CO}}
$$

The resulting fuel gas has a high $\mathrm{H}_{2}$ and $\mathrm{CO}_{2}$ content, even if it is quite diluted due to the presence of nitrogen. Thus, the next step is the removal of the carbon dioxide, facilitated by the obtained high concentration (table 2).

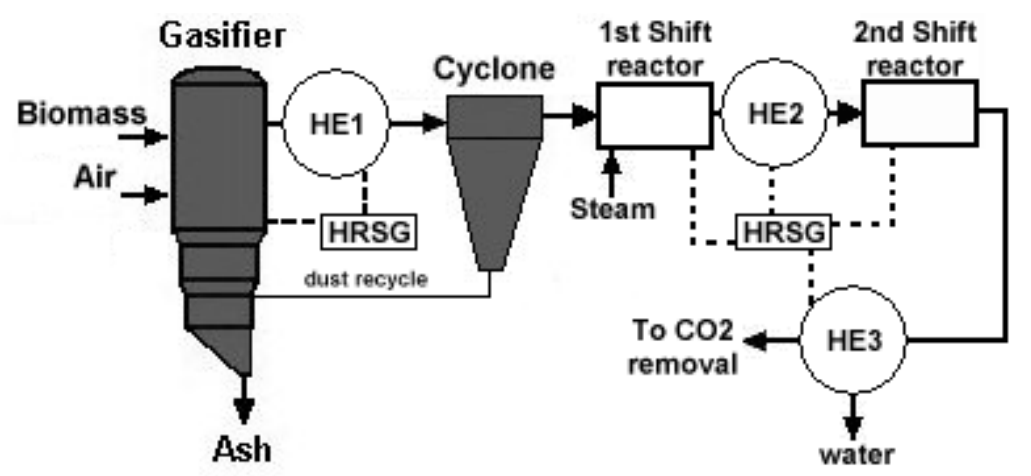

Figure 2 Schematic of the gasification and shift reaction section

Due to the exothermic nature of the reaction, both the reactors are provided with heat recovery, in order to maintain the temperatures at fixed values and to minimize the losses. 
Two more heat exchangers have been included in the scheme. The first one (HE2) cools the gas after the first shift reactor down to the inlet temperature of the second shift reactor. The second heat exchanger (HE3) cools the gas downstream the second reactor down to the inlet temperature of the $\mathrm{CO}_{2}$ removal section $\left(30^{\circ} \mathrm{C}\right)$.

The $\mathrm{H}_{2} \mathrm{O} / \mathrm{CO}$ ratio was set equal to 2 (Chiesa and Consonni 1998, Hendriks 1994, Kohl and Riesenfeld 1985), hence, the required steam flow rate is $31.9 \mathrm{~kg} / \mathrm{s}$.

The gasifier temperature ( $\left.T_{G A S}\right)$ and the first heat exchanger temperature $\left(T_{H E 1}\right)$ have been defined by means of a partial exergetic analysis (Carpentieri 2001). The values that maximize the exergy balance are $\mathrm{T}_{\mathrm{GAS}}=1100^{\circ} \mathrm{C}$ and $\mathrm{T}_{\mathrm{HE} 1}=270^{\circ} \mathrm{C}$.

\begin{tabular}{|l|c|c|}
\hline Flow rate [kg/s] & \multicolumn{2}{|c|}{70.94} \\
\hline Temperature [ ${ }^{\circ} \mathbf{C}$ ] & \multicolumn{2}{|c|}{30} \\
\hline Pressure [bar] & \multicolumn{2}{|c|}{1.01325} \\
\hline Composition & Mass fraction & Mole fraction \\
\hline $\mathbf{H}_{\mathbf{2}} \mathbf{O}$ & $\mathbf{3 . 9} \%$ & $\mathbf{4 . 2} \%$ \\
\hline $\mathbf{C O}_{2}$ & $\mathbf{6 5 . 1} \%$ & $\mathbf{2 8 . 6} \%$ \\
\hline $\mathbf{N}_{\mathbf{2}}$ & $\mathbf{2 5 . 1} \%$ & $\mathbf{1 7 . 3} \%$ \\
\hline $\mathbf{H}_{\mathbf{2}}$ & $\mathbf{5 . 2} \%$ & $\mathbf{4 9 . 5} \%$ \\
\hline $\mathbf{C O}$ & $\mathbf{0 . 2} \%$ & $\mathbf{0 . 1} \%$ \\
\hline $\mathbf{A r}$ & $\mathbf{0 . 5} \%$ & $\mathbf{0 . 2} \%$ \\
\hline $\mathrm{HCl}$ & $380 \mathrm{ppm}$ & $201 \mathrm{ppm}$ \\
\hline $\mathrm{H}_{2} \mathrm{~S}$ & $38 \mathrm{ppm}$ & $21 \mathrm{ppm}$ \\
\hline $\mathrm{CH}$ & $3 \mathrm{ppm}$ & $3 \mathrm{ppm}$ \\
\hline $\mathrm{COS}$ & $2 \mathrm{ppm}$ & $0.8 \mathrm{ppm}$ \\
\hline $\mathrm{NH}_{3}$ & $4 \mathrm{ppm}$ & $4 \mathrm{ppm}$ \\
\hline $\mathrm{HCN}$ & $1 \mathrm{ppm}$ & $0.8 \mathrm{ppm}$ \\
\hline $\mathrm{NO}_{3} \mathrm{SO}_{2}, \mathrm{C}_{2} \mathrm{H}_{6}$ & \multicolumn{2}{|c|}{ Trace } \\
\hline $\mathrm{LHV}[\mathrm{kJ} / \mathrm{kg}]$ & \multicolumn{2}{|c|}{6217} \\
\hline
\end{tabular}

Table 2 Syngas features exiting the shift reaction section

\section{3. $\mathrm{CO}_{2}$ REMOVAL}

Chemical absorption has been selected because it is a well-developed technology and is particularly suitable for quite high $\mathrm{CO}_{2}$ concentration (Eliasson 1998). The absorbing medium is an aqueous amine blended solution, which is regenerated by means of temperature swing (TSA Temperature swing absorption process). According to previous study (Corti and Manfrida 1999), using the appropriate blend of DEA (diethanolamine) and MDEA (methyldiethanolamine) it is 
possible to keep the regeneration heat requirement lower than $4 \mathrm{MJ} / \mathrm{kgCO}_{2 \mathrm{REMOVED}}$. The system consists of an absorption tower (inlet streams: raw syngas, water and amines; outlet streams: cleaned syngas and solution loaded with $\mathrm{CO}_{2}$ ) and a stripper to regenerate the solution. A more detailed description can be found in (Corti and Lombardi 1998).

With reference to the specific syngas composition, the most suitable solution blend has been investigated (Carpentieri 2001, Corti and Lombardi 2002), considering total amine content (mass fraction) equal to 30,40 and $50 \%$ and varying the DEA and MDEA mass fractions.

$50 \%$ amine solutions allow reaching defined $\mathrm{CO}_{2}$ removal efficiency with lower solution mass flow rate and hence lower energy requirement than the less concentrated solutions.

Results for different DEA and MDEA mass fractions, for a total content of $50 \%$, considering $80 \%$ $\mathrm{CO}_{2}$ removal efficiency (to be comparable with previous studies (Corti and Manfrida 1999, Corti and Lombardi 1998)), showed a maximum value for the cycle power output (i.e. maximum cycle efficiency, being constant the biomass input) - hence a minimum $\mathrm{CO}_{2}$ removal energy requirement - corresponding to a $20 \%$ DEA and $30 \%$ MDEA composition (figure 3). Specific energy requirement is about $3.4 \mathrm{MJ} / \mathrm{kgCO}_{2 \mathrm{REMOVED}}$, that is supplied in part by means of regenerative heat recovery (lean/load solution heat exchanger) and in part by steam extraction in the power section. This condition corresponds to a required solution mass flow rate $(557 \mathrm{~kg} / \mathrm{s})$ - determinant for plant investment cost definition - not minimized, but not far from the minimum value $(531 \mathrm{~kg} / \mathrm{s})$ obtained for a $30 \%$ DEA and $20 \%$ MDEA composition (figure 4).

The characteristics and composition of syngas exiting $\mathrm{CO}_{2}$ removal section are reported in table 3 : the heating value is almost doubled, with respect to the entering syngas, due to the removal of diluting $\mathrm{CO}_{2}$.

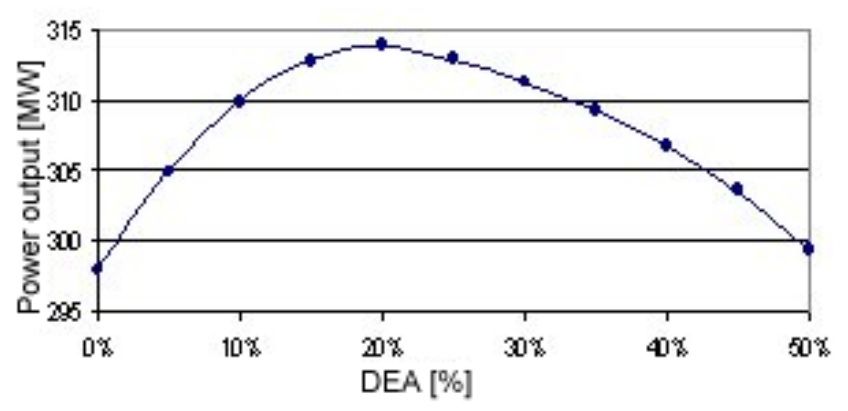

Figure 3 Power output vs. solution composition 


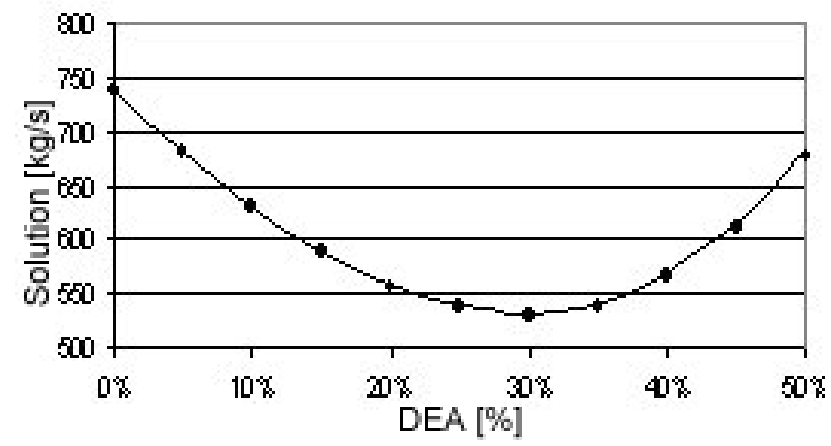

Figure 4 Solution mass flow rate vs. solution composition

\begin{tabular}{|c|c|c|}
\hline \multirow{3}{*}{$\begin{array}{l}\text { Flow rate }[\mathrm{kg} / \mathrm{s}] \\
\text { Temperature }\left[{ }^{\circ} \mathrm{C}\right] \\
\text { Composition }\end{array}$} & \multirow{2}{*}{\multicolumn{2}{|c|}{$\begin{array}{c}38.82 \\
554\end{array}$}} \\
\hline & & \\
\hline & Mass fraction & Mole fraction \\
\hline $\mathrm{H}_{2} \mathrm{O}$ & $19.6 \%$ & $13.6 \%$ \\
\hline $\mathrm{CO}_{2}$ & $23.8 \%$ & $6.8 \%$ \\
\hline $\mathbf{N}_{2}$ & $45.9 \%$ & $20.5 \%$ \\
\hline $\mathrm{H}_{2}$ & $9.4 \%$ & $58.6 \%$ \\
\hline CO & $0.3 \%$ & $0.2 \%$ \\
\hline $\mathrm{Ar}$ & $0.8 \%$ & $0.3 \%$ \\
\hline $\mathrm{H}_{2} \mathrm{~S}$ & 60 ppm & 22 ppm \\
\hline $\mathrm{HCl}$ & $658 \mathrm{ppm}$ & $226 \mathrm{ppm}$ \\
\hline MDEA & $135 \mathrm{ppm}$ & 14 ppm \\
\hline DEA & 4 ppm & $0.4 \mathrm{ppm}$ \\
\hline $\mathrm{CH}_{4}$ & $5 \mathrm{ppm}$ & 4 ppm \\
\hline $\cos$ & $4 \mathrm{ppm}$ & $0.8 \mathrm{ppm}$ \\
\hline $\mathrm{NH}_{3}$ & $5 \mathrm{ppm}$ & 4 ppm \\
\hline $\mathrm{HCN}$ & $2 \mathrm{ppm}$ & $0.7 \mathrm{ppm}$ \\
\hline $\mathrm{SO}_{2}, \mathrm{NO}, \mathrm{C}_{2} \mathrm{H}_{6}$ & Trace & Trace \\
\hline LHV [kJ/kq] & 11364 & kJ/kg \\
\hline
\end{tabular}

Table 3 Syngas features exiting the $\mathrm{CO}_{2}$ removal section

\section{POWER GENERATION SECTION}

The power generation scheme is a conventional Brayton/Hirn combined cycle, with the addition of the syngas compressor and the heat recoveries in the different syngas treatment sections. Gas turbine (GT) operating conditions have been defined according to a reference technology level: corresponding to an aero-derivative GT, with the characteristics summarized in table 4.

For the syngas compression up to the combustion chamber pressure, a three-staged intercooled compressor has been considered (2.5, 7 and 19 bar). 


\begin{tabular}{|l|c|}
\hline GT inlet temperature $\left[{ }^{\circ} \mathrm{C}\right]$ & 1258 \\
\hline GT outlet temperature $\left[{ }^{\circ} \mathrm{C}\right]$ & 537 \\
\hline Compressor outlet temperature $\left[{ }^{\circ} \mathrm{C}\right]$ & 454 \\
\hline Compression ratio & 19 \\
\hline
\end{tabular}

Table 4 GT reference technology operating conditions

A two-pressure levels steam bottoming cycle has been considered with high pressure (HP) steam at 40 bar and $450{ }^{\circ} \mathrm{C}$, and low pressure (LP) steam at 2.5 bar and $168.1^{\circ} \mathrm{C}$.

Heat recoveries from different cycle sections - in addition to the heat recovery steam generator (HRSG) from GT exhausts - have been arranged in order to maximize the produced steam flow rate.

\section{SIMULATION RESULTS}

Simulation results are reported in table 5. Syngas compression work represents a high fraction of the total combined cycle power output, about $18.5 \%$, and quite greatly contributes to the efficiency reduction with respect to a pressurized ICGCC (46.6\%) in a conventional configuration or with $\mathrm{CO}_{2}$ chemical absorption (38.8\%) (Fiaschi and Lombardi 2001).

The additional consumption - of $355 \mathrm{~kJ} / \mathrm{kg}_{\mathrm{co} 2}$ (Lombardi 2003) - for $\mathrm{CO}_{2}$ compression up to 80 bar was considered.

\begin{tabular}{|c|c|c|c|}
\hline Syngas compressor power [kW] & 37,929 & ST power (HP) [kW] & 37,255 \\
\hline Air compressor power $[\mathrm{kW}]$ & 192,666 & ST power (LP) [kW] & 17,900 \\
\hline GT power [kW] & 379,942 & Pump power [kW] & 511 \\
\hline GT net power [MW] & 149.347 & ST net power [MW] & 55.155 \\
\hline \multicolumn{3}{|l|}{$\mathrm{CO}_{2}$ compressor power $[\mathrm{MW}]$} & 13 \\
\hline \multicolumn{3}{|l|}{ Combined cycle net power [MW] } & 191.386 \\
\hline \multicolumn{3}{|c|}{ Efficiency [\%] } & 33.94 \\
\hline \multicolumn{3}{|c|}{ Specific $\mathrm{CO}_{2}$ emissions [kg $\left.\mathrm{co}_{2} / \mathrm{MWh}\right]$} & 178 \\
\hline
\end{tabular}

Table $5 \mathrm{IBGCC}+\mathrm{DeCO}_{2}$ simulation results (ST=steam turbine)

Specific $\mathrm{CO}_{2}$ emissions can be directly compared with values obtained from previous studies

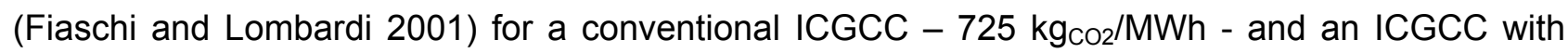


$\mathrm{CO}_{2}$ removal $-130 \mathrm{~kg} \mathrm{co}_{2} / \mathrm{MWh}$. Specific $\mathrm{CO}_{2}$ emissions can be also compared with other published results (table 6).

\begin{tabular}{|c|c|c|}
\hline Reference & $\begin{array}{c}\text { Specific } \mathrm{CO}_{2} \\
\text { emission [kg/MWh] }\end{array}$ & Notes \\
\hline Present paper & 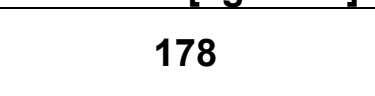 & $\begin{array}{l}\text { IBGCC + } \mathrm{CO}_{2} \text { removal } \\
\text { (chemical absorption) }\end{array}$ \\
\hline Fiaschi and Lombardi 2001 & 725 & Conventional ICGCC \\
\hline Fiaschi and Lombardi 2001 & 130 & $\begin{array}{c}\text { ICGCC }+\mathrm{CO}_{2} \text { removal } \\
\text { (chemical absorption) }\end{array}$ \\
\hline Hendriks 1994 & 800 & $\begin{array}{l}\text { Conventional pulverised coal } \\
\text { steam cycle (PCSC) }\end{array}$ \\
\hline Hendriks 1994 & 760 & Conventional ICGCC \\
\hline Hendriks 1994 & 100 & $\begin{array}{l}\mathrm{PCSC}+\mathrm{CO}_{2} \text { removal } \\
\text { (chemical absorption) }\end{array}$ \\
\hline Hendriks 1994 & 250 & $\begin{array}{l}\mathrm{PCSC}+\mathrm{CO}_{2} \text { removal } \\
\text { (membrane separation) }\end{array}$ \\
\hline Hendriks 1994 & 40 & $\begin{array}{l}\text { ICGCC + } \mathrm{CO}_{2} \text { removal } \\
\text { (chemical absorption) }\end{array}$ \\
\hline Chiesa et al. 1999 & 709 & Conventional ICGCC \\
\hline Chiesa et al. 1999 & 73 & $\begin{array}{l}\mathrm{ICGCC}+\mathrm{CO}_{2} \text { removal } \\
\text { (chemical absorption) }\end{array}$ \\
\hline Chiesa et al. 1999 & 71 & $\begin{array}{c}\text { ICGCC + } \mathrm{CO}_{2} \text { removal } \\
\text { (physical absorption) }\end{array}$ \\
\hline Chiesa and Consonni 1998 & 377 & $\begin{array}{c}\text { Conventional natural gas } \\
\text { combined cycle }\end{array}$ \\
\hline Chiesa and Consonni 1998 & 747 & Conventional ICGCC \\
\hline Chiesa and Consonni 1998 & 74 & $\begin{array}{c}\text { ICGCC + } \mathrm{CO}_{2} \text { removal } \\
\text { (chemical absorption) }\end{array}$ \\
\hline Lombardi 2003 & 388 & $\begin{array}{l}\text { Coal semi-closed gas turbine } \\
\text { combined cycle (CSCGT/CC) }\end{array}$ \\
\hline Lombardi 2003 & 65 & $\begin{array}{l}\mathrm{CSCGT} / \mathrm{CC}+\mathrm{CO}_{2} \text { removal } \\
\text { (chemical absorption) }\end{array}$ \\
\hline Mann and Spath 1997 & 916 & Conventional IBGCC \\
\hline
\end{tabular}

Table 6 Specific $\mathrm{CO}_{2}$ emission comparison (biomass-fed plants are in bold)

IBGCC+DeCO ${ }_{2}$ has definitely a better conversion efficiency and specific $\mathrm{CO}_{2}$ emissions with respect to biomass direct combustion in steam cycle configuration: $23 \%$ and about 1400 $\mathrm{kg}_{\mathrm{CO} 2} / \mathrm{MWh}(\mathrm{EREN} 2001)$. 


\section{LIFE CYCLE ASSESSMENT (LCA)}

A life cycle assessment study consists of several phases: goal and scope definition, inventory analysis, impact assessment and interpretation and improvement (ISO 14040 1998). In the following each step is described with regard to this work.

The first stage is the "Goal definition and scoping", as described in the ISO 14041 (1998), and it includes the definition of the functional unit.

The aim of this work is to assess the environmental impact, on a life cycle horizon, of the biomass utilization in energy production. The contributions of the different life cycle phases to the overall impacts are highlighted in order to assess the most impacting phases. Further, a comparison with an analogous LCA study of a similar energy conversion cycle fed with coal (ICGCC) was carried out.

The reference functional unit for the inventory analysis and impact assessment is the energy production of $1 \mathrm{MJ}$.

The considered system includes: biomass production and transportation, plant construction, energy conversion (operating life 15 years) and plant maintenance, plant dismantling (see table 6). In the biomass production and transportation phase were considered within the boundaries: the chemical processes for the production of fertilisers and herbicides, the use of these substances for the biomass cultivation, the biogenic emissions from the biomass, the $\mathrm{CO}_{2}$ sequestration due to photosynthesis of biomass, the production of fuel and its utilisation in the machines for the biomass cultivation, the production of fuel and its utilisation for the biomass transportation. The construction of the buildings necessary for the biomass cultivation and the construction of the machines were not accounted for (Rafaschieri et al. 1999) and considered negligible.

The plant construction includes: the production of raw materials required for the plant devices and the emission due to the assembly of materials.

The operating phase consists of: water consumption for $\mathrm{CO}_{2}$ removal section and steam cycle, amines production, regeneration of activated carbons, raw materials production for maintenance, stack emissions, process wastes. 
The dismantling phase comprises energy consumption for dismantling, recycling and transportation of materials.

Thus the whole system has been schematised in the inventory analysis in term of raw material input and output emissions (solid, liquid and gaseous).

\section{LCA - INVENTORY ANALYSIS}

Any product or service needs to be represented as a system in the inventory analysis methodology. A system is defined as a collection of materially and energetically connected operations (e.g. manufacturing process, transport process, fuel extraction process) which perform some defined function. The inventory analysis is a quantitative description of all flows of materials and energy across the system boundary either into or out of the system itself (ISO 14041 1998). The considered processes are summarised in table 7.

\begin{tabular}{|c|c|}
\hline \multicolumn{2}{|c|}{ Plant construction } \\
\hline \multirow{2}{*}{ Biomass production } & Biomass cultivation \\
\cline { 2 - 2 } & Biomass transportation \\
\hline \multirow{2}{*}{ Operating phase } & Energy conversion \\
\cline { 2 - 2 } & Maintenance \\
\hline \multicolumn{2}{|c|}{ Plant dismantling } \\
\hline
\end{tabular}

Table 7 Processes for LCA

The considered biomass production ratio is equal to 13.4 ton per hectare per year, with a cultivation cycle of seven years (Mann and Spath 1997).

Mainly the use of agricultural machines for seeding, growing and collection phases and the use of pesticides and fertilizers have been considered using data according to (Mann and Spath 1997) and summarized in table 8 . No consumption of water and energy for watering has been considered, since it has been assumed that all the required water is supplied by rainfall. 


\begin{tabular}{|c|c|}
\hline $\mathrm{N}$-fertilizers application (50/50 urea and ammonium nitrate) & $100 \mathrm{~kg} / \mathrm{ha}$ (nitrate) during $4^{\text {th }}$ year \\
\hline P-fertilizers application & $22,4 \mathrm{~kg} / \mathrm{ha}$ (as $\mathrm{P}$ ) during $1^{\text {st }}$ year \\
\hline K-fertilizers application $\left(\mathrm{K}_{2} \mathrm{O}\right)$ & $39.2 \mathrm{~kg} / \mathrm{ha}($ as $\mathrm{K})$ during $1^{\mathrm{st}}$ year \\
\hline Pre-emergency herbicide (Oust ${ }^{\top \mathrm{M}}$ ) application & $36.5 \mathrm{~cm}^{3}$ a.s./ha during $1^{\text {st }}$ and $2^{\text {nd }}$ years \\
\hline Post-emergency herbicide (Roundup ${ }^{\mathrm{TM}}$ ) application & $36.5 \mathrm{~cm}^{3}$ a.s. $/$ ha during $1^{\text {st }}$ and $2^{\text {nd }}$ years \\
\hline Pesticide application & Not considered \\
\hline
\end{tabular}

Table 8 Biomass growing phase data

Fuel consumption for agricultural machines has been calculated, with reference to the operations in table 8, using emission factors in (Mann and Spath 1997) and (EMEP/CORINAIR 1999). No contribution due to construction and dismantling of agricultural machines has been considered.

Atmospheric emission factors for the use of fertilizers and pesticides/herbicides have been retrieved respectively from (EMEP/CORINAIR 1999) and (Rafaschieri et al. 1999).

Data for the production processes of manufactured materials entering the system (fertilizers, pesticides/herbicides, fuels, electricity, etc.) have been retrieved from LCA devoted databases (SimaPro 1997, I-LCA 2000).

Carbon dioxide assimilated by the biomass during the growing phase corresponds to the amount of carbon in the biomass composition, equal to $48 \%$ in mass. Hence, for each kilogram of carbon in the biomass about $3.67 \mathrm{~kg}$ of carbon dioxide have been subtracted from the atmosphere.

Biomass transportation average distance has been assumed equal to $75 \mathrm{~km}$, covered by truck. Atmospheric emissions and fuel consumptions have been calculated with the help of (EMEP/CORINAIR 1999).

Moreover, a $20 \%$ loss of dry substance during ambient conditions drying process has been considered (Rafaschieri et al. 1999).

For the construction phase the main materials have been considered (steel, cast iron, aluminium, copper, plastic, rubber asphalt and cement), accounting for their production processes (SimaPro 1997). The amounts of these materials have been estimated by a rough sizing of the main devices in the plant and with reference to a similar plant fed with coal (Lombardi 2003), up-scaling or downscaling the devices. Further, the on-site energy consumption for construction has been considered, too (Lombardi 2003). 
Inventory data for the energy production phase come from the IBGCC Aspen Plus simulation (Carpentieri 2001) and are reported in table 9.

\begin{tabular}{|c|c|}
\hline Compound & Mass fraction \\
\hline $\mathrm{O}_{2}$ & $12.94 \%$ \\
\hline $\mathrm{N}_{2}$ & $71.70 \%$ \\
\hline $\mathrm{Ar}$ & $0.92 \%$ \\
\hline $\mathrm{H}_{2} \mathrm{O}$ & $13.08 \%$ \\
\hline $\mathrm{CO}_{2}$ & $1.26 \%$ \\
\hline $\mathrm{CO}$ & $0.06 \mathrm{ppm}$ \\
\hline $\mathrm{NH}_{3}$ & Trace \\
\hline $\mathrm{H}_{2}$ & $0.2 \mathrm{ppm}$ \\
\hline $\mathrm{HCl}$ & $41 \mathrm{ppm}$ \\
\hline $\mathrm{NO}$ & $0.1 \%$ \\
\hline $\mathrm{SO}_{2}$ & $4 \mathrm{ppm}$ \\
\hline $\mathrm{NO}_{2}$ & $15 \mathrm{ppm}$ \\
\hline $\mathrm{SO}_{3}$ & $0.2 \mathrm{ppm}$ \\
\hline
\end{tabular}

Table 9 Stack emissions data

Contributions from device maintenance - basically material consumption for worn-out part substitution (Lombardi 2003) - have been accounted for, using SimaPro database (SimaPro 1997). Data for the activated carbons regeneration have been retrieved from (SimaPro 1997), too. Inventory data for amines production was not available because the required data are proprietary information.

In order to give an estimation of the error connected to neglecting the input consumption (Lombardi, 2001), mainly energy, and pollutants emissions during the production process of amines, data for the production processes of other chemicals have been taken from SimaPro (SimaPro 1997). Choosing, for example, two chemicals, respectively with low and very high energy requirement for the production process, it is possible to estimate the range within the error varies. Among the chemicals in SimaPro, Ureum I (CASE 1), with an energy input of $17.9 \mathrm{MJ} / \mathrm{kg}$, and the toluene-diisocyanate - and in particular the record named TDI I - (CASE 2), with an energy input of $145 \mathrm{MJ} / \mathrm{kg}$, have been chosen, just as representing very different values of energy-intensive chemical products. 
In (Lombardi, 2001) it is possible to verify that the influence on the results considering the above range is very low.

Hence, in the following the input amount of consumed amines has been substituted with the same amount of the high energy consuming chemical, considering the worse possible case.

Concerning the dismantling phase, energy consumption and the connected emissions for the on-site work and recycling processes have been considered (Lombardi 2003). The material recycle is considered as negative emissions in the avoided production of new materials. The SimaPro database was used for this phase.

\section{LCA - IMPACT ASSESSMENT}

Life cycle impact assessment (ISO/CD 14042 1999) examines the mass and energy inventory input and output data for a product system to translate these data to better identify their possible environmental relevance and significance. This translation uses, where possible, numerical indicators for specific subjects or categories, where the indicator reflects in some manner the system environmental loading or resource depletion for that category. These indicators then constitute an environmental loading and resource depletion profile for a system. This profile with possible further analysis and weighting is intended to provide an additional useful perspective on the possible environmental significance in one or more general areas of resources, natural environment and human health.

In this study, the results of the impact assessment are presented according to the Eco-indicator'95 methodology (Goedkoop 1995), whose indicators are summarised in table 10, with the respective units.

\begin{tabular}{|c|c|}
\hline Greenhouse effect [ $\mathrm{kg}_{\mathrm{cO} 2}$ eq./f.u.] & Winter smog [kgspm eq./f.u.] \\
\hline Ozone layer depletion [kg $\mathrm{kFC11}_{\mathrm{CF}}$ eq./f.u.] & Summer smog [kg ${ }_{\mathrm{C} 2 \mathrm{H} 4}$ eq./f.u.] \\
\hline Acidification [kgso4 eq./f.u.] & Pesticides [kg act.s. $/$ f.u.] \\
\hline Eutrophication [kg $\mathrm{kgO} 2_{\mathrm{s}}$ eq./f.u.] & Energy [MJ/f.u.] \\
\hline Heavy metals [kg $\mathrm{kg}_{\mathrm{pb}}$ eq./f.u.] & Solid waste [kg/f.u.] \\
\hline Carcinogenic substances [kg $\mathrm{kg}_{\mathrm{B}(\mathrm{a}) \mathrm{P}}$ eq./f.u.] & \\
\hline
\end{tabular}

Table 10 Reference indicators for impact assessment. 
Besides the indicators of Eco-Indicator 95 methodology, two more indicators were considered: Energy and Solid waste. The former was considered in order to account for raw materials consumption (in terms of LHV), the latter takes into account the production of waste and, hence, it is related to the land use for landfilling.

\section{LCA - RESULTS}

The final stage of LCA is the interpretation phase (ISO/DIS 14043 1999), where inventory analysis and impact assessment results are summarized and discussed.

Results, referred to the functional unit - $1 \mathrm{MJ}$ of energy production - are reported in table 10 and in figure 5. The different phase contributions (plant construction, biomass production and transport, energy conversion and maintenance, plant dismantling) are also shown.

\begin{tabular}{|c|c|c|c|c|c|c|c|}
\hline \multirow[b]{2}{*}{ Indicator } & \multirow{2}{*}{$\begin{array}{c}\text { Plant } \\
\text { construction }\end{array}$} & \multicolumn{2}{|c|}{ Fuel production } & \multicolumn{2}{|c|}{ Operating } & \multirow[b]{2}{*}{ Dismantling } & \multirow[b]{2}{*}{ TOTAL } \\
\hline & & $\begin{array}{l}\text { Biomass } \\
\text { production }\end{array}$ & Transport & $\begin{array}{c}\text { Energy } \\
\text { Conversion }\end{array}$ & Maintenance & & \\
\hline Greenhouse effect [kg] & $2,50 \cdot 10^{-4}$ & -0.228 & 0.012 & 0.0509 & $2.90 \cdot 10^{-5}$ & $-5 \cdot 10^{-6}$ & -0.165 \\
\hline Ozone Layer Depl. [kg] & $2 \cdot 10^{-12}$ & $6.9 \cdot 10^{-9}$ & $2 \cdot 10^{-9}$ & $2.4 \cdot 10^{-8}$ & $3.46 \cdot 10^{-13}$ & $8 \cdot 10^{-12}$ & $3.26 \cdot 10^{-8}$ \\
\hline Acidification [kg] & $6.5 \cdot 10^{-6}$ & $5 \cdot 10^{-4}$ & $9 \cdot 10^{-6}$ & 0.002 & $7.84 \cdot 10^{-7}$ & $6 \cdot 10^{-8}$ & 0.00251 \\
\hline Eutrophication [kg] & $1.3 \cdot 10^{-7}$ & $1.2 \cdot 10^{-4}$ & $8 \cdot 10^{-7}$ & $3.4 \cdot 10^{-4}$ & $1.29 \cdot 10^{-8}$ & $4 \cdot 10^{-9}$ & $4.62 \cdot 10^{-4}$ \\
\hline Heavy Metals [kg] & $5.3 \cdot 10^{-9}$ & $1.2 \cdot 10^{-7}$ & $2 \cdot 10^{-8}$ & $4.8 \cdot 10^{-9}$ & $1.15 \cdot 10^{-9}$ & $-1 \cdot 10^{-10}$ & $1.54 \cdot 10^{-7}$ \\
\hline Winter smog [kg] & $4.6 \cdot 10^{-11}$ & $7.1 \cdot 10^{-9}$ & $8 \cdot 10^{-10}$ & $1.3 \cdot 10^{-12}$ & $4.63 \cdot 10^{-12}$ & $-1 \cdot 10^{-11}$ & $7.92 \cdot 10^{-9}$ \\
\hline Summer smog [kg] & $1 \cdot 10^{-5}$ & $7.4 \cdot 10^{-5}$ & $5 \cdot 10^{-6}$ & $2.6 \cdot 10^{-5}$ & $6.89 \cdot 10^{-7}$ & $-5 \cdot 10^{-9}$ & $1.16 \cdot 10^{-4}$ \\
\hline Carcinogenic sub.[kg] & $3.2 \cdot 10^{-7}$ & $4 \cdot 10^{-5}$ & $8 \cdot 10^{-6}$ & $9.3 \cdot 10^{-7}$ & $8.45 \cdot 10^{-9}$ & $-6 \cdot 10^{-7}$ & $4.89 \cdot 10^{-5}$ \\
\hline Pesticides [kg] & 0 & $1.17 \cdot 10^{-6}$ & 0 & 0 & 0 & 0 & $1.17 \cdot 10^{-6}$ \\
\hline Energy [MJ] & 0.0048 & 0.151 & 0.0123 & 0.130 & $4.43 \cdot 10^{-4}$ & -0.0021 & 0.296 \\
\hline Solids [kg] & $2.1 \cdot 10^{-4}$ & $2.5 \cdot 10^{-5}$ & $6 \cdot 10^{-6}$ & $7.8 \cdot 10^{-5}$ & $2.45 \cdot 10^{-6}$ & $5 \cdot 10^{-6}$ & $3.24 \cdot 10^{-4}$ \\
\hline
\end{tabular}

Table 11 LCA results (functional unit, f.u.=1 MJ) 


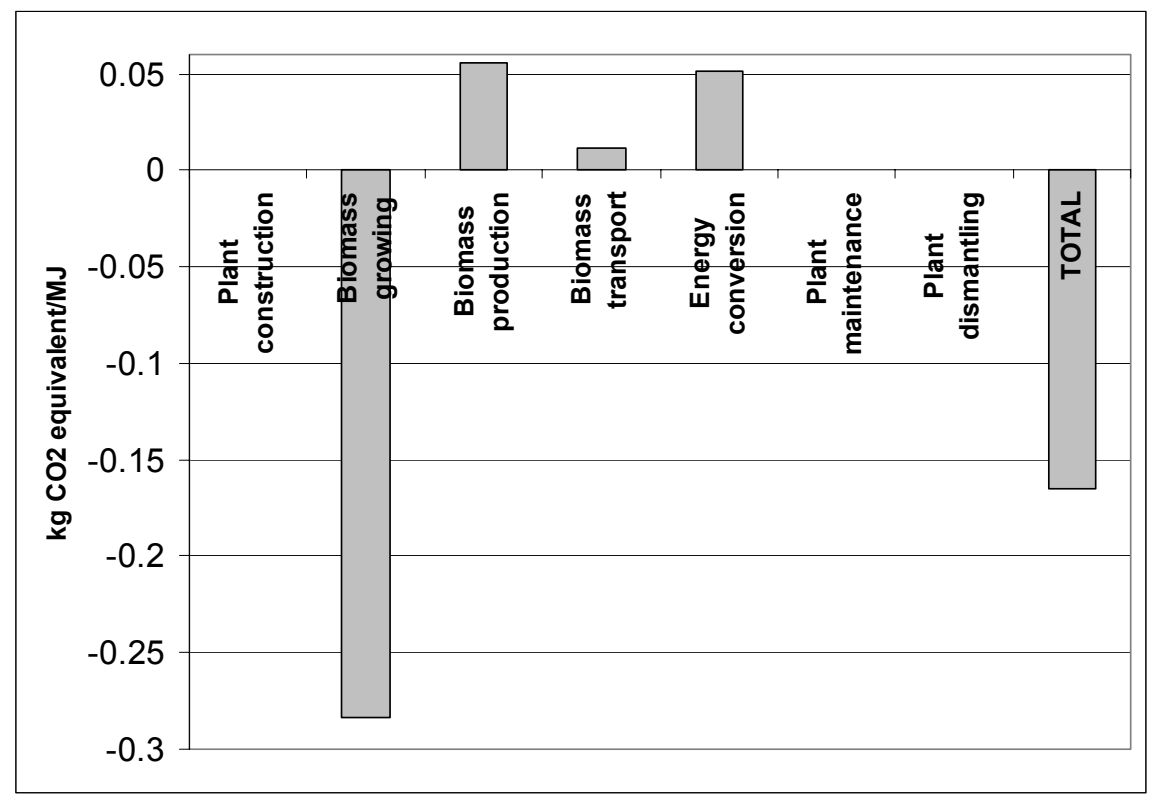

Figure 5 Greenhouse effect indicator

As a matter of fact (see figure 5), the contribution of the plant construction, maintenance and dismantling to the greenhouse effect indicator is negligible with respect to other phases.

Main contributions come from energy conversion and biomass production (except biomass growing).

The biomass $\mathrm{CO}_{2}$ sequestration during cultivation seems to be crucial for the greenhouse effect indicator. Due to this contribution the indicator value becomes negative, meaning a substantial subtraction of equivalent $\mathrm{CO}_{2}$ from atmosphere.

In fact, the $\mathrm{CO}_{2}$ balance shows a more than $100 \%$ closure (finally there is less $\mathrm{CO}_{2}$ in the atmosphere). In absence of the $\mathrm{CO}_{2}$ removal section, the balance closure would have not been complete (about 90\%) (Corti et al. 2002). It is reasonable to suppose that if also the final $\mathrm{CO}_{2}$ disposal was considered the balance closure would be lower than what presently found, since additional emissions would be due to the transportation process and final storage (in deep ocean (Golomb et al. 1989, Golomb and Angelopoulos 2000, IEA 2001), in exhausted oil reservoirs (IEA 2001), in aquifers (IEA 2001)). These additional processes were not considered in the present study and it would be worth to analyse also this phase in case of available data about it. 
Figure 6 shows the final Eco-indicator values, for each considered phase, calculated according to the Eco-Indicator 95 methodology (Goedkoop 1995), after normalisation and weighting of the indicators in table 11. The final Eco-indicator allows the comparison of the different production stages: construction and dismantling are negligible compared to other processes; operating phase is the worst process from an environmental point of view.

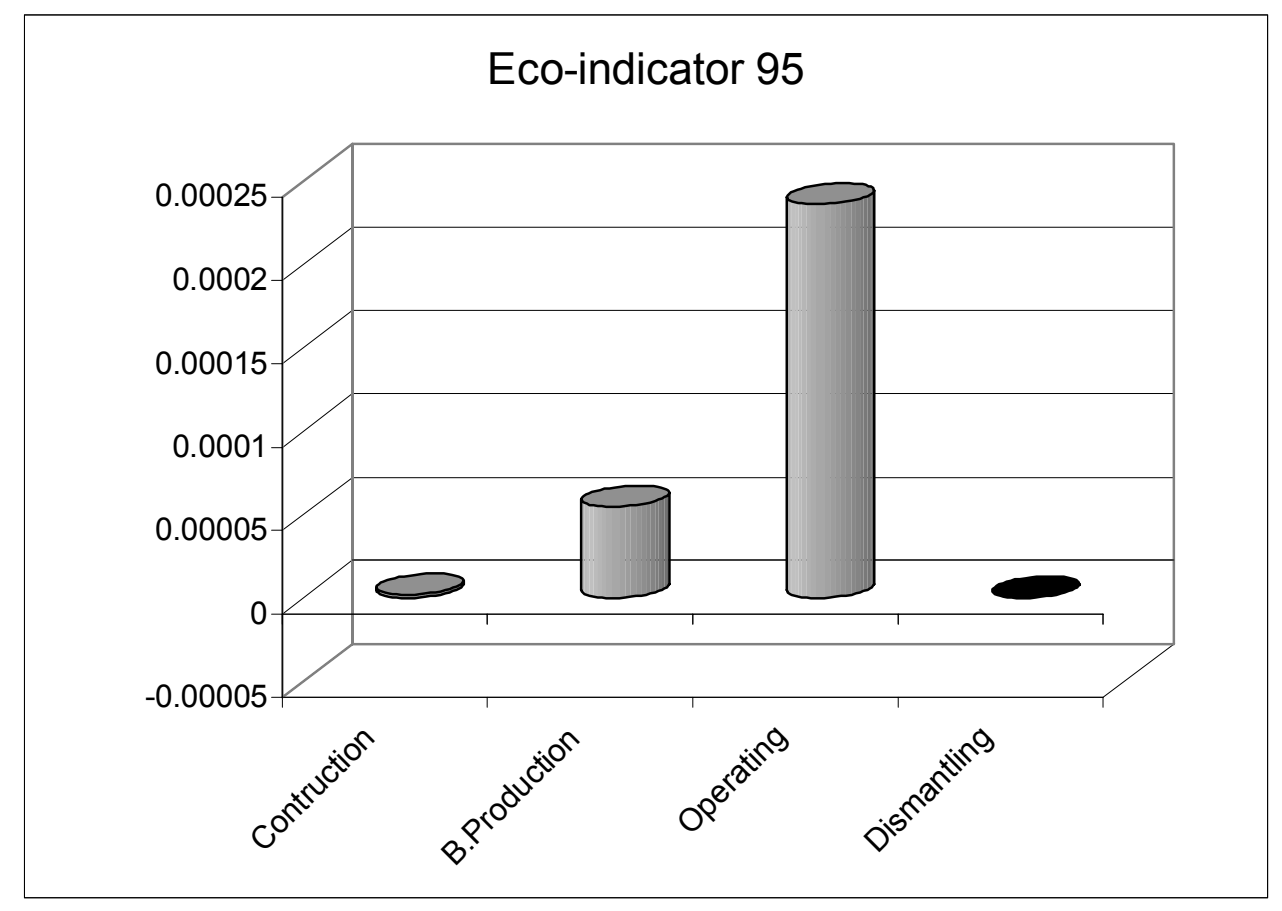

Figure 6 Eco-indicator 95 value

\section{COMPARISON WITH ICGCC}

To better highlight the results of LCA performed in this paper, they have been compared with an analogous LCA of an ICGCC (Integrated Coal Gasification Combined Cycle) with $\mathrm{CO}_{2}$ removal (Lombardi, 2003). In that previous study the same data were used for the construction, maintenance and dismantling of the plant, accounting for the different devices. A similar process simulation was carried out (Lombardi 2003) using Aspen Plus, which has provided stack emissions data as in this case. The plant outline was the same of the IBGCC plant, except for:

- the presence of a pressurised gasifier fed with coal (thus the absence of a compression stage before syngas utilisation in the combustion chamber); 
- the presence of $\mathrm{a} \mathrm{H}_{2} \mathrm{~S}$ removal section;

- the absence of the biomass cultivation and transportation phase (substituted by coal mining and transportation).

Figure 7 shows the comparison of the IBGCC greenhouse effect indicator with the greenhouse effect indicator for the ICGCC (Lombardi, 2003). It is interesting to highlight the high IBGCC impact, when the $\mathrm{CO}_{2}$ sink due to biomass photosynthesis is not included in the calculation. In fact, in this case, the biomass production and transport impact, for the IBGCC, is higher than the coal extraction impact, in the ICGCC, while the operating phase has a similar impact in both cases (Corti et al. 2002).

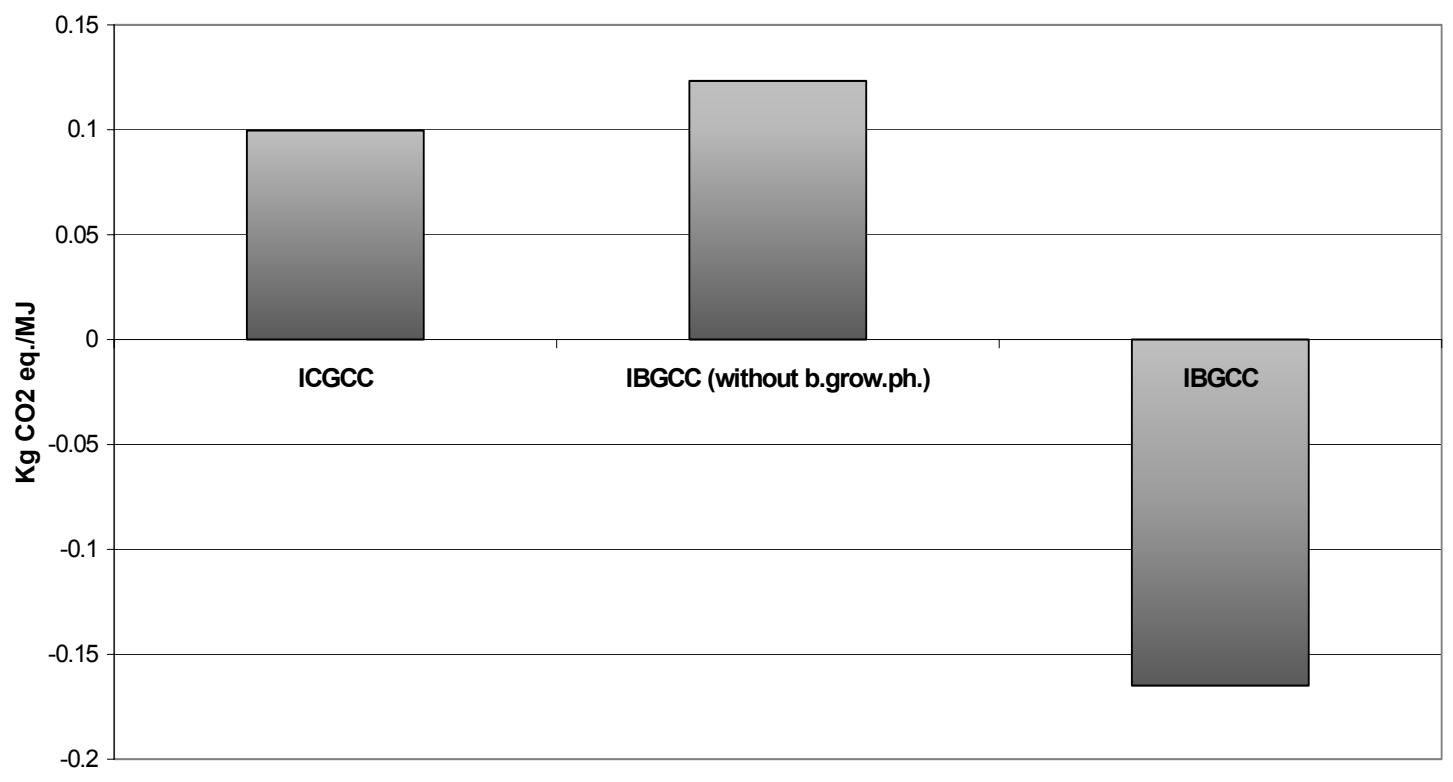

Figure 7 Greenhouse effect indicator comparison 


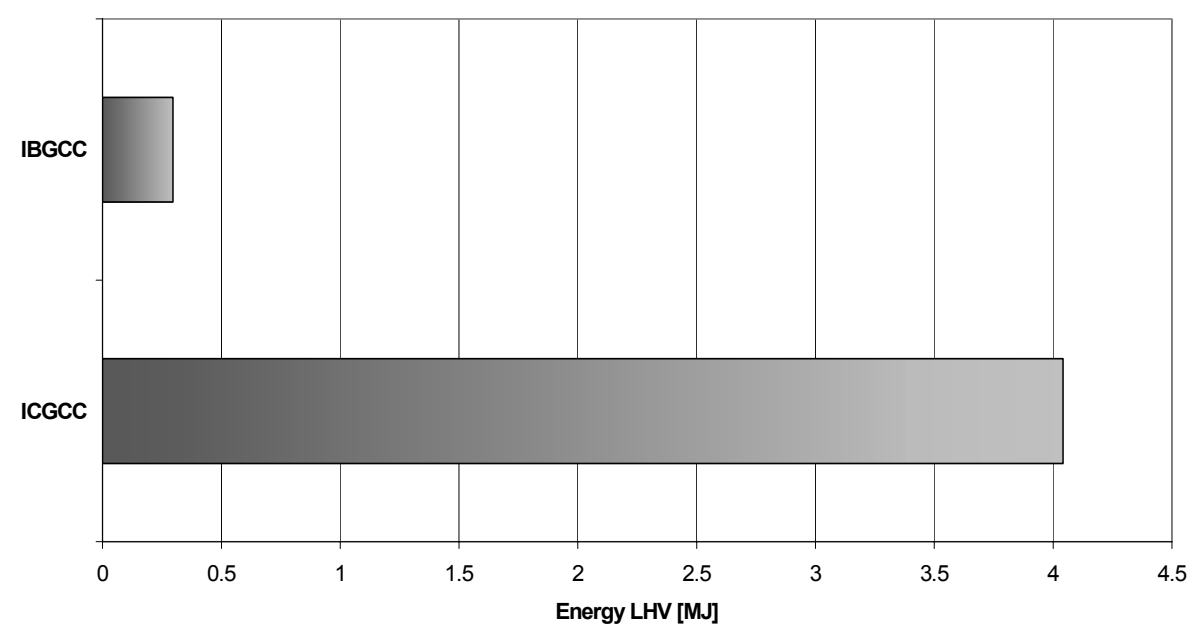

Figure 8 Energy indicator comparison

Figure 8 shows the results for the energy indicator, addressing the issue of resource depletion. The advantage of renewable resource (biomass) utilisation instead of conventional fuel is evident.

Pesticides indicator was not compared because the value of this indicator is zero in the case of ICGCC.

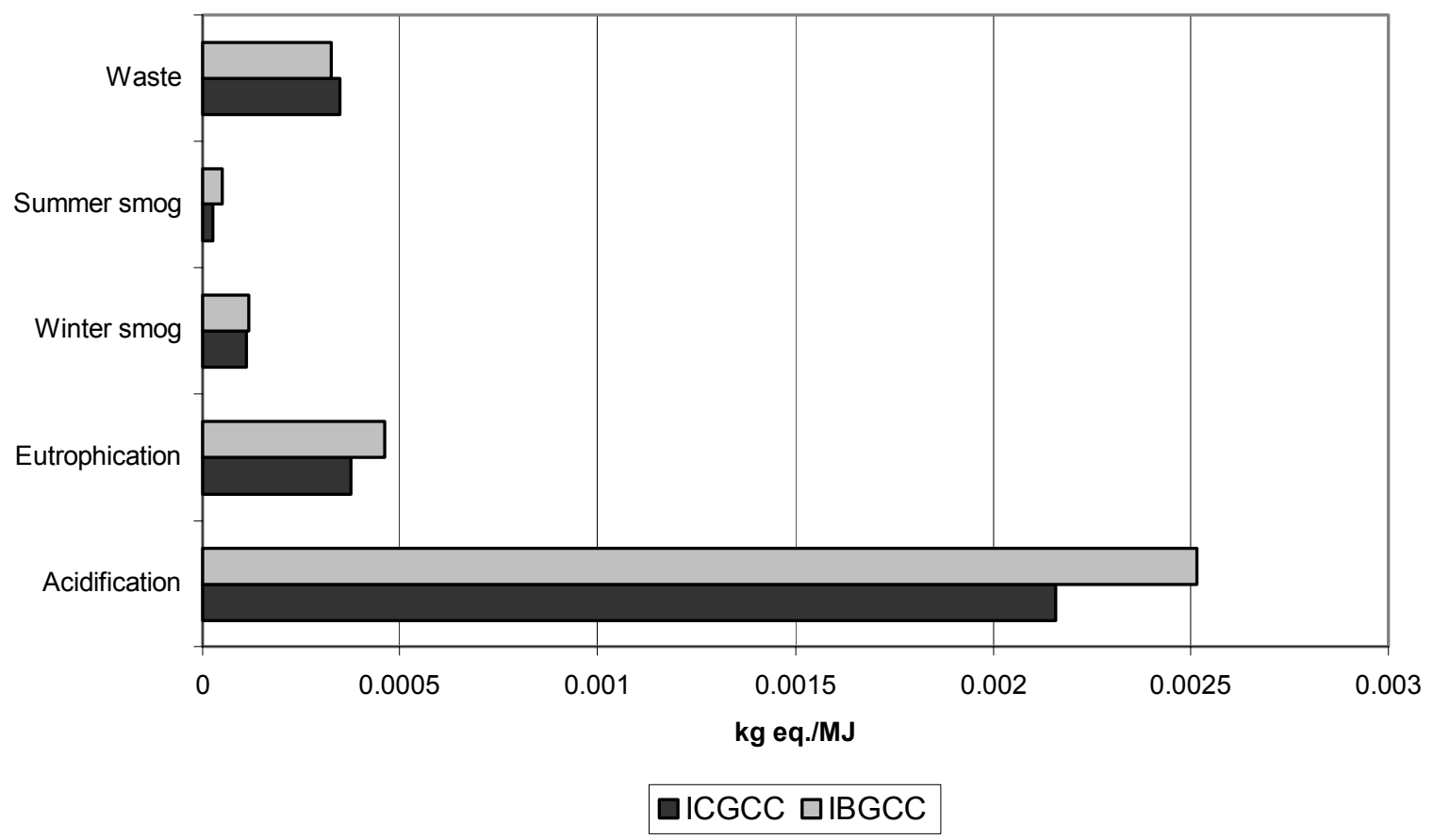

Figure 9 Acidification, eutrophication, winter smog, summer smog and solid waste indicators comparison 


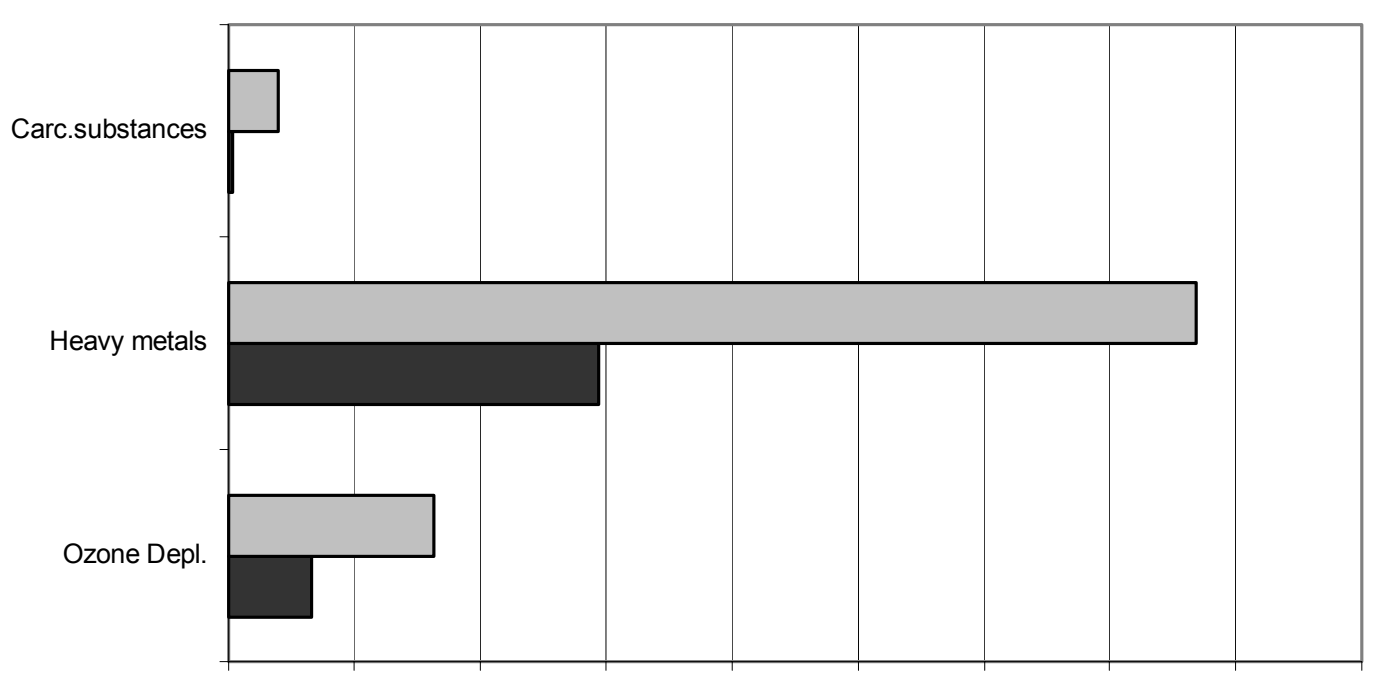

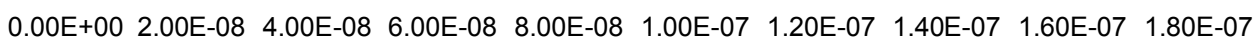

kg eq./MJ

ICGCC $\square$ IBGCC

Figure 10 Ozone layer depletion, heavy metals and carcinogenic substances indicators comparison

On the contrary, for each of the other indicators, the results seem to be similar, even if the coal values are a little lower than biomass values (figure 9 and figure 10). This is due both to the elevated impact of biomass production phase (in particular for acidification, eutrophication, heavy metals and carcinogenic substances) and to the lower energy conversion efficiency of the IBGCC (see the figures 11 to 13 ).

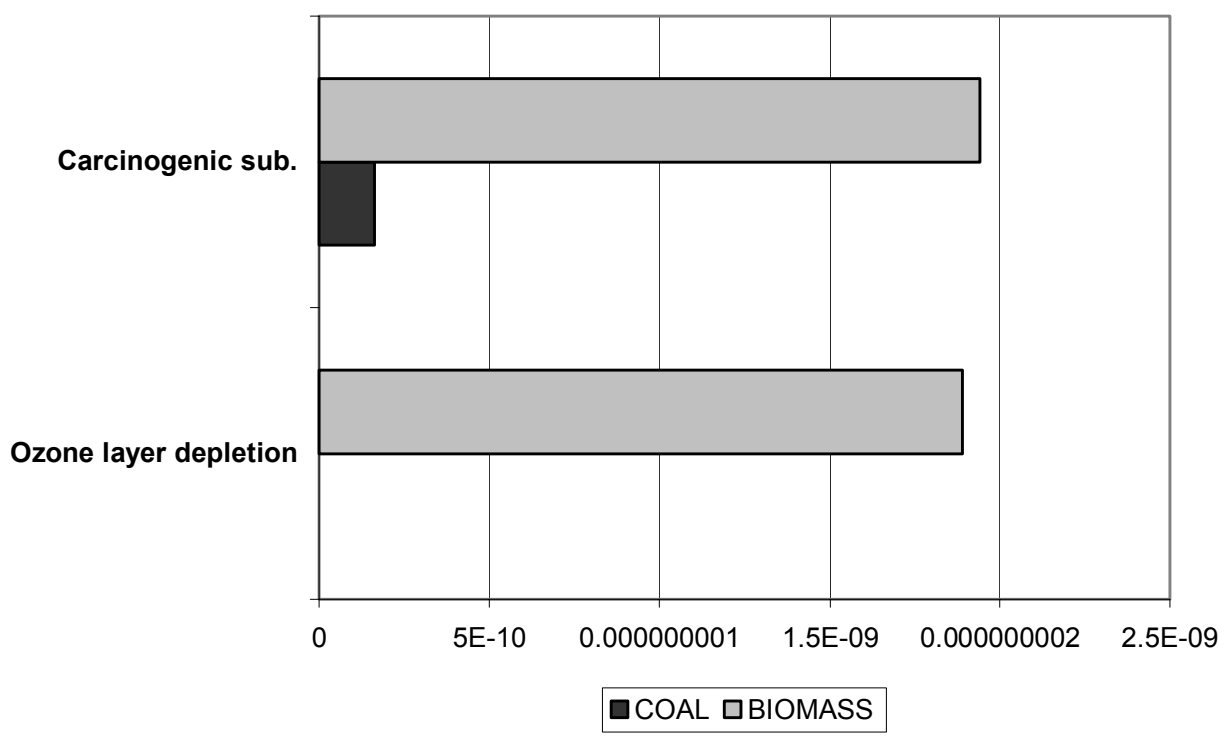

Figure 11 Fuel production phase comparison (carcinogenic substances and ozone layer depletion indicators). The f.u. is $1 \mathrm{MJ}$ LHV 


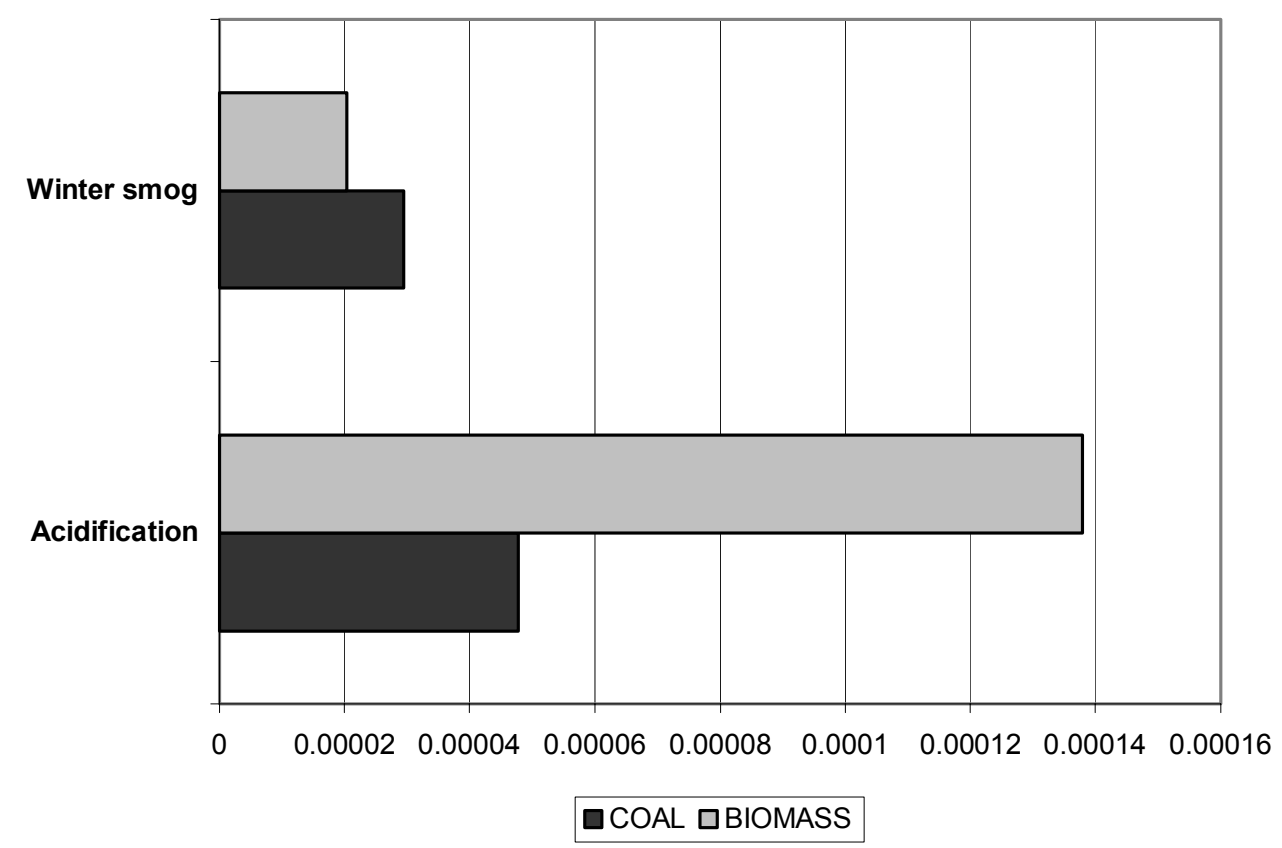

Figure 12 Fuel production phase comparison (winter smog and acidification indicators). The f.u. is $1 \mathrm{MJ}$ LHV

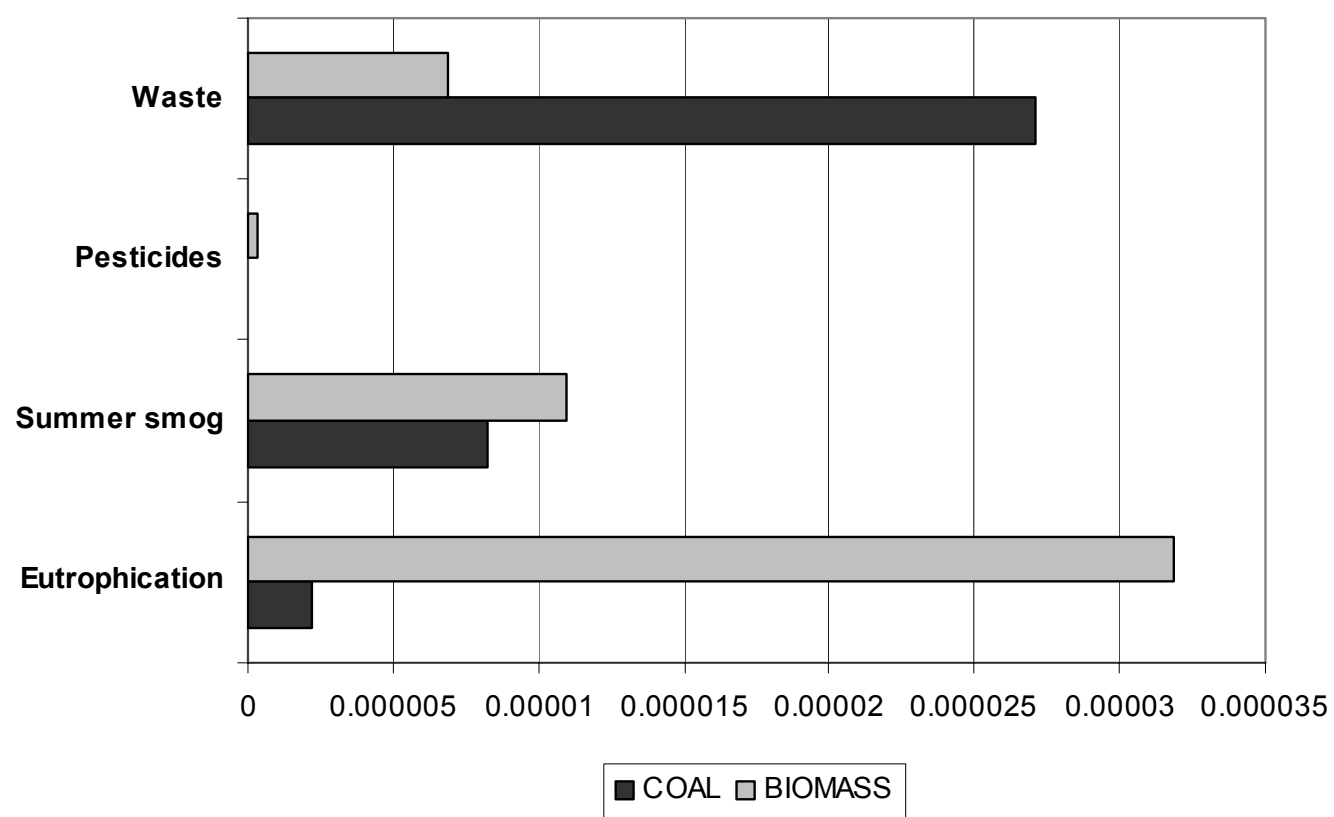

Figure 13 Fuel production phase comparison (solid waste, pesticides, summer smog and eutrophication indicators). The f.u. is 1 MJ LHV 


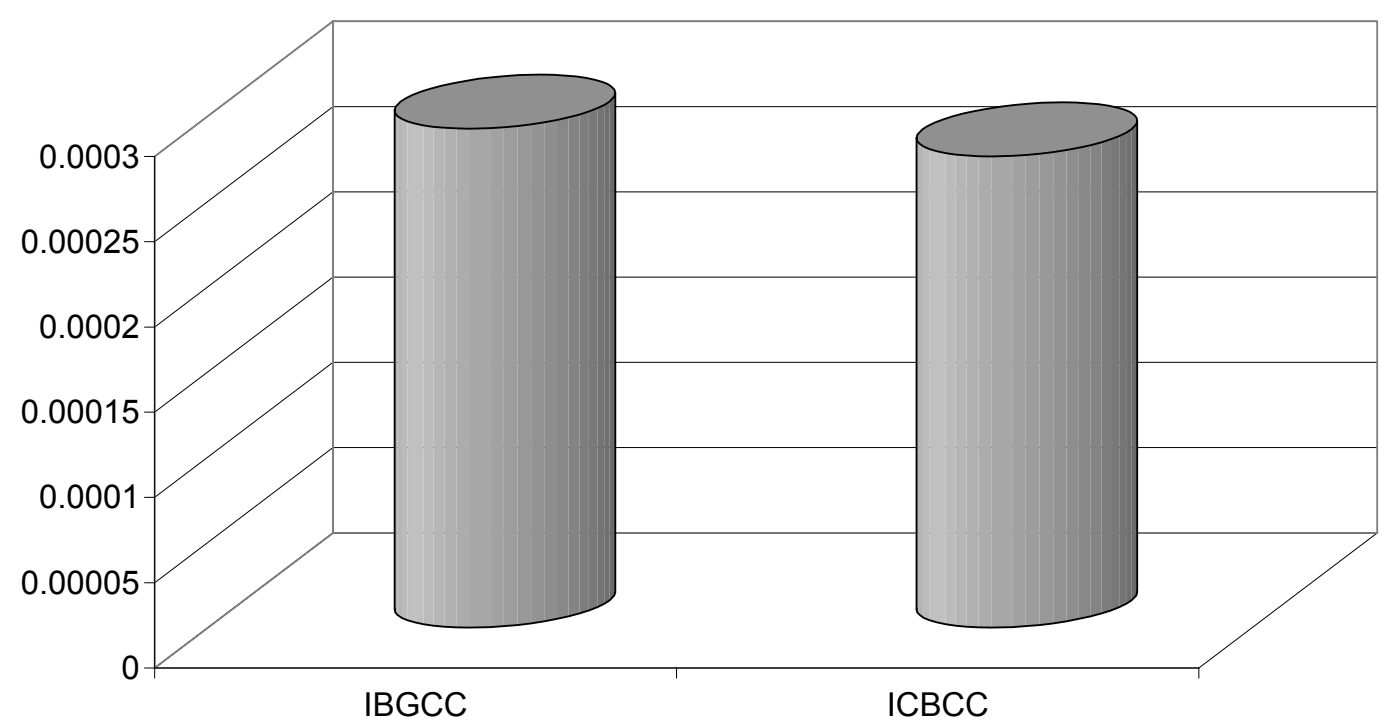

Figure 14 Global comparison

Finally, the Eco-Indicator 95 methodology (Goedkoop 1995) was used to calculate the final Ecoindicator associated to the two cycles. As shown in figure 14, the two Eco-indicators are comparable, with a result slightly better for the coal. Nevertheless a comment is necessary: the Eco-Indicator 95 methodology is very incomplete in this case, because it takes into account for only the material emissions to the environment, ignoring, for example, the advantages due to the utilization of a renewable energy as the biomass (energy and solid waste indicators are not included in the final indicator calculation). Thus a more general comparison between the two options, by means of a more complete methodology, as the Eco-Indicator 99 (Goedkoop and Spriensma 2000) or the CML guidelines (Guinée et al. 2001), is required.

\section{CONCLUSIONS}

The simulation of an IBGCC+DeCO 2 has shown interesting cycle efficiency, $33.94 \%$, with specific $\mathrm{CO}_{2}$ emissions of $178 \mathrm{~kg}_{\mathrm{co} 2} / \mathrm{MWh}$ (with a fixed $80 \% \mathrm{CO}_{2}$ removal efficiency).

If compared with a similar coal IGCC+DeCO (efficiency $=38.8 \%$, specific $\mathrm{CO}_{2}$ emissions $=130$ $\mathrm{kg}_{\mathrm{CO} 2} / \mathrm{MWh}$ ) these results seem to be competitive. A five points efficiency reduction is mainly due to the inevitable syngas compression. 
LCA methodology application has shown, as an evident result, a negligible contribution to the overall environmental impact by plant construction and dismantling, with respect to biomass production and, especially, to plant operating phase.

Another result is the confirmation of a renewable resource (as the biomass) utilisation superiority with respect to coal utilisation, in term of natural resource depletion and avoided greenhouse gas emissions.

The results concerning the other indicators show values slightly higher than the $I_{C G C C}+D e C O_{2}$, due to the minor IBGCC+DeCO ${ }_{2}$ efficiency as well as the non-negligible impact caused by energy crops cultivation.

For a more definitive conclusion a more complete methodology is necessary in order to account for all the environmental implications of the considered processes. Moreover, a further improvement might result from a better description of the cultivation phase. In fact, literature data on energy crops cultivation are widely incomplete and there are a lot of possible developments.

\section{REFERENCES}

AspenTech. 2001. ASPEN PLUS ${ }^{\mathrm{TM}}$ User Guide; Release 10.1-0. Cambridge, Massachusetts, USA: Aspen Technology Inc.

Carpentieri, M. 2001. Modello termodinamico per la valutazione energetica di un ciclo di gassificazione della biomassa a ridotte emissioni di $\mathrm{CO}_{2}$ [Thermodynamic model for energy evaluation of a biomass gasification cycle with reduced $\mathrm{CO}_{2}$ emission]. Firenze, Italy: Degree thesis in Environmental Engineering, University of Florence.

Chiesa, P. and S. Consonni. 1998. Shift reactors and physical absorption for low-CO $\mathrm{C}_{2}$ emission IGCCs. Draft manuscript for $43^{\text {rd }}$ ASME Gas Turbine and Aeroengine Congress, 2-5 June, Stockholm, Sweden.

Chiesa, P., S. Consonni and G. Lozza. 1999. A comparative analysis of IGCCs with $\mathrm{CO}_{2}$ sequestration. In Greenhouse Gas Control Technologies, edited by R. Riemer, B. Eliasson and A. Wokaun. Oxford, UK: Elsevier science. 
Corti, A. and L. Lombardi. 1998. Analysis of Different Blended Amines Solutions for CO2 Removal from a Semi Closed GT Power Plant. Proceedings of International Conference ECOS98, 810 July 1998, Nancy, France.

Corti, A. and G. Manfrida. 1999. Economic analysis of a semi-closed gas turbine/combined cycle (SCGT/CC) with $\mathrm{CO}_{2}$ removal by amines absorption. In Greenhouse Gas Control Technologies, edited by R. Riemer, B. Eliasson and A. Wokaun. Oxford, UK: Elsevier science.

Corti, A. and L. Lombardi. 2002. Performance analysis of a biomass integrated gasification combined cycle with reduced $\mathrm{CO}_{2}$ emissions. Proceeding of International Conference ECOS 2002, 3-5 July 2002, Berlin, Germany.

Corti, A., L. Lombardi and M. Carpentieri. 2002. Impiego di biomassa in ciclo energetico ad alto rendimento: studio impiantistico e bilancio ambientale mediante metodologia LCA [Biomass utilization in a high efficiency energy production cycle: performance analysis and environmental balance by means of LCA methodology]. Proceedings of VI SIBESA 2002, 15 September 2002, Vitoria, Brazil.

Domalski, E.S. and T.L. Jobe jr. 1987. Thermodynamic data for biomass materials and waste components. New York, USA: The ASME research committee on industrial and municipal waste.

Eliasson, B. 1998. The power industry and the $\mathrm{CO}_{2}$ issue. Liege, Belgium: Workshop on zero emission power plants, University of Liege.

EMEP/CORINAIR. 1999. Emission Inventory Guidebook. Copenhagen, Denmark: European Environment Agency.

EREN. 2001. Direct fire biomass. Report on Burlington plant, Vermont (USA). http://ereb.doe.gov/power/pdfs/direct_fire_bio.pdf. Energy Efficiency and Renewable Energy Network, U.S. Department of Energy. Accessed February 2001.

Fiaschi, D. and L. Lombardi. 2001. IGCC plant with integrated $\mathrm{CO}_{2}-\mathrm{H}_{2} \mathrm{~S}$ removal: performance analysis and life cycle assessment. Proceedings of International Conference ECOS 2001, 4-6 July 2001, Istanbul, Turkey: ICAT. 
Goedkoop, M. 1995. The Eco-indicator 95, final report. Amersfoort, The Netherlands: PRé Consultants B.V.- NOH.

Goedkoop, M. and R. Spriensma. 2000. The Eco-indicator 99: a damage oriented method for life cycle assessment, methodology report. Amersfoort, The Netherlands: PRé Consultants B.V.

Golomb, D., H. Herzog, J. Tester, D. White and S. Zemba. 1989. Feasibility, Modeling and Economics of sequestering Power Plant $\mathrm{CO}_{2}$ Emissions in the Deep Ocean. Massachusetts Institute of Technology.

Golomb, D. and A. Angelopoulos. 2000. A Benign Form of $\mathrm{CO}_{2}$ Sequestration in the Ocean. Proceedings of GHGT-5, Cairns, Australia, 2000.

Guinée, J., M. Gorrée, R. Heijungs, G. Huppes, R. Kleijn, A. Wegener Sleeswijk, H. A. Udo de Haes, J. A. de Bruijn and R. van Duin. 2001. Life Cycle Assessment : an operational guide to the ISO standards. Leiden, The Netherlands: Centre of Environmental Science (CML), University of Leiden.

Hendriks, C. 1994. Carbon dioxide removal from coal-fired power plants. Dordrecht, The Netherlands: Kluwer Academic Publishers.

IEA (International Energy Agency). 2001. Web site of the IEA Greenhouse Gas R\&D Programme, http://www.ieagreen.org.uk. Accessed February 2002.

I-LCA. 2000. Italian database for LCA inventory analysis, version 2 October 2000. Roma, Italy: ANPA.

ISO 14040. 1998. Environmental management - Life cycle assessment - Principles and framework.

ISO 14041. 1998. Environmental management - Life cycle assessment - Goal and scope definition and life cycle inventory analysis.

ISO/CD 14042. 1999. Environmental management - Life cycle assessment - Life cycle impact assessment.

ISO/DIS 14043. 1999. Environmental management - Life cycle assessment - Life cycle interpretation. 
Kohl, A.L. and F.C. Riesenfeld. 1985. Gas purification. Houston, Texas, USA: Gulf Publishing Company.

Lombardi, L. 2001. Life cycle assessment (LCA) and exergetic life cycle assessment (ELCA) of a semi-closed gas turbine cycle with $\mathrm{CO}_{2}$ chemical absorption. Energy Conversion and Management 42(1): 101-114.

Lombardi, L. 2003. LCA comparison of technical solutions for $\mathrm{CO}_{2}$ emission reduction in power generation. Energy conversion and management 44(1): 93-108.

Mann, M.K. and P.L. Spath. 1997. Life cycle assessment of a biomass gasification combined-cycle power system. Golden, Colorado, USA: National Renewable Energy Laboratory.

PRé Consultants. 1997. SIMAPRO, Database Manual. Amesfoort, The Netherlands: PRé Consultants B.V.

Rafaschieri, A., M. Rapaccini and G. Manfrida. 1999. Life Cycle Assessment of electricity production from poplar energy crops compared with conventional fossil fuels. Energy Conversion and Management 40(14): 1477-1493.

Williams, R.H. and E.D. Larson. 1996. Biomass gasifier gas turbine power generating technology. Biomass and Bioenergy 10(2-3): 149-166. 